\title{
ANALISIS PENERAPAN LANGKAH-LANGKAH PEMBELAJARAN DENGAN PENDEKATAN SAINTIFIK DALAM KURIKULUM 2013 PADA PEMBELAJARAN BIOLOGI DI SMA NEGERI SE-KOTA MEDAN
}

\author{
Oleh: \\ Jimmy Francius Simbolon 1), \\ dan Jhonas Dongoran 2) \\ Sekolah Tinggi Keguruan Dan Ilmu Pendidikan (STKIP) Riama Medan 1,2) \\ E-mail: \\ kevkez2015@gmail.com ${ }^{1}$, \\ dan dongoran231089@gmail.com ${ }^{2)}$
}

\begin{abstract}
Scientific approach is one of approach applied in the Curriculum of 2013. The Scientific approach designed student as the subject of learning and teacher as a facilitator and motivator. In this design, teacher is not must explain all of the teaching material. There are 5 steps of the scientific approach which is abbreviated into 5M as follows: observing, asking, gathering information, reasoning, and communicating. The Objective of this study are (1) to measure the scientific approach application in the curriculum of 2013 in High Schools of Medan City, (2) to find out the obstacles commonly faced by Biology teachers in the application of scientific approach in the Curriculum of 2013 in State High Schools in Medan and (3) to find out the school facilities and infrastructure that supports the application of the scientific approach in the Curriculum of 2013 at State High Schools in Medan. This research was conducted in State High School in Medan City. The research held on July - September 2019. The research applied descriptive method to find out the application of scientific approach steps in State High School in Medan City. The instruments in this study were observation, questionnaire, and interview. The data were analyzed by the scientific approach data analysis and also by the analysis of observation data. This research is targeted to be publishes in any National non-Accredited Journal. The TKT proposed in this research is on a scale of 1 which shows the basic principles of learning technology with a recorded scientific approach.

Keywords: scientific approach, biology education, medan state high school.
\end{abstract}

\begin{abstract}
ABSTRAK
Pendekatan saintifik merupakan salah satu pendekatan yang diterapkan dalam Kurikulum 2013.Dalam pendekatan saintifik, peserta didik sebagai subjek pembelajaran, sedangkan guru hanya sebagai fasilitator dan motivator.Sehingga guru tidak perlu menjelaskan semua tentang apa yang ada dalam materi pembelajaran. Langkah-langkah pendekatan saintifik yaitu 5M: mengamati, menanya, mengumpulkan informasi, menalar dan mengkomunikasikan. Tujuan penelitian ini adalah (1) untuk mengetahui penerapan pendekatan saintifik dalam Kurikulum 2013 di SMA Negeri Se-Kota Medan, (2) untuk mengetahui kendala yang dihadapi guru Biologi dalam penerapan pendekatan saintifik dalam Kurikulum 2013 di SMA Negeri Se-Kota Medan dan (3) untuk mengetahui sarana dan prasarana sekolah yang mendukung penerapan pendekatan saintifik dalam Kurikulum 2013 di SMA Negeri Se-Kota Medan. Penelitian ini dilaksanakan di SMA Negeri Se-Kota Medan.Penelitian ini dilaksanakan pada Juli - September 2019.Metode penelitian yang digunakan adalah metode deskriptif untuk mengetahui bagaimana penerapan langkah-langkah pendekatan saintifik di SMA Negeri Se-Kota Medan. Instrumen dalam penelitian ini adalah observasi, angket, dan wawancara. Metode analisa data yang dilakukan adalah Analisa Data Penerapan Pendekatan Saintifik dan Analisa Data Observasi.Luaran yang ditargetkan adalah jurnal nasional tidak terakreditasi publikasi tahun 2019. TKT yang diusulkan berada pada skala 1 yang menunjukan prinsip dasar dari teknologi pembelajaran dengan pendekatan saintifik dan dilaporkan.
\end{abstract}

Kata kunci: pendekatan saintifik, pendidikan biologi, sma negeri se-kota medan 


\section{PENDAHULUAN}

Dalam Undang-Undang Republik Indonesia Nomor 20 tahun 2003 tentang Sisdiknas, bahwa pendidikan merupakan usaha sadar dan terencana untuk mewujudkan suasana belajar dan proses pembelajaran agar peserta didik secara aktif mengembangkan potensi dirinya untuk memiliki kekuatan spiritual keagamaan, pengendalian diri, kepribadian, kecerdasan, akhlak mulia, serta keterampilan yang diperlukan oleh dirinya sendiri, masyarakat bangsa dan Negara (Kemdikbud, 2013).

Pembelajaran dengan menggunakan "pendekatan saintifik" adalah proses pembelajaran yang dirancang sedemikian rupa agar peserta didik secara aktif mengonstruk konsep, hukum atau prinsip melalui tahapantahapan mengamati (untuk mengidentifikasi atau menemukan masalah), merumuskan masalah, mengajukan atau merumuskan hipotesis, mengumpulkan data dengan berbagai teknik, menganalisis data, menarik kesimpulan dan mengomunikasikan konsep, hukum atau prinsip yang "ditemukan" (Saubas, 2015).

Sesuai dengan Permendikbud No. 65 tahun 2013 tentang Standar Proses, Kurikulum 2013 menggunakan pendekatan ilmiah (saintifik) sebagai pendekatan pokok yang perlu diperkuat dengan pembelajaran berbasis penyingkapan (discovery learning), pembelajaran berbasis penelitian (inquiry learning), dan pembelajaran berbasis proyek (project based learning). Keberhasilan pelaksanaan Kurikulum 2013 sangat ditentukan oleh keberhasilan guru dalam mengembangkan pembelajaran berdasarkan pendekatan atau model pembelajaran aktif tersebut (Prihadi, 2014).

Kurikulum 2013 memiliki ciri khas tersendiri yaitu adanya penerapan pendidikan pendekatan saintifik atau ilmiah dalam proses pembelajarannya. Kemendikbud memberikan konsepsi tersendiri bahwa pendekatan ilmiah atau saintifik approach dalam pembelajaran mencakup komponen: mengamati, menanya, mencoba, mengolah, menyajikan, menyimpulkan, dan mencipta.Komponenkomponen tersebut seyogyanya dapat dimunculkan dalam setiap praktik pembelajaran, tetapi bukanlah sebuah siklus pembelajaran (Sani, 2014).

Tujuan pembelajaran dengan pendekatan saintifik antara lain untuk: (1) meningkatkan kemampuan intelektual, khususnya kemampuan berpikir tingkat tinggi siswa, (2) membentuk kemampuan siswa dalam menyelesaikan suatu masalah secara sistematik, (3) memperoleh hasil belajar yang tinggi, (4) melatih siswa dalam mengomunikasikan ide-ide, khususnya dalam menulis karya ilmiah, serta (5) mengembangkan karakter siswa (Prihadi, 2014). Dalam proses mengamati yang menggunakan panca indera siswa, sangat bermanfaat bagi pemenuhan rasa ingin tahu sehingga proses pembelajaran memiliki kebermaknaan yang tinggi. Setelah proses mengamati akan muncul pertanyaan di pikiran siswa tentang apa, mengapa, kapan, di mana, siapa serta bagaimana tentang suatu permasalahan yang diberikan. Kemudian siswa mulai berpikir logis dan sistematis atas fakta-fakta empiris yang dapat diobservasi untuk memperoleh kesimpulan berupa pengetahuan baru yang nantinya bisa dikomunikasikan atau disampaikan kepada orang-orang disekitarnya. Dari proses pembelajaran dengan pendekatan saintifik, diharapkan suatu pembelajaran yang semula dianggap membosankan karena bersifat hafalan dapat berubah menjadi aktivitas pembelajaran yang menyenangkan dan bermakna bagi siswa. Siswa juga dapat menguasai materi dengan baik dan mengembangkan karakter yang diharapkan dalam proses pembelajaran yang berlangsung.

Dalam Kurikulum 2013 dengan pendekatan saintifik, peran guru tidak kalah penting. Guru diharapkan memiliki kompetensi pedagogik, profesional, personal dan sosial dalam menunjang proses belajar mengajar. Kompetensi pedagogik mendapat penekanan khusus pada Kurikulum 2013 karena guru harus mampu mendorong dan menginspirasi siswa untuk dapat memahami, menerapkan, dan mengembangkan pola berpikir yang rasional dan objektif dalam merespon materi pembelajaran.

Pembelajaran dengan pendekatan saintifik yang berpusat pada siswa membuat pembelajaran menjadi bermakna sehingga 
akan membantu dalam meningkatkan hasil belajar biologi siswa. Pembelajaran Biologi tidak hanya sebatas memberikan informasi atau pemindahan pengetahuan dari guru kepada siswa, akan tetapi menjadi suatu kewajiban bahwa pembelajaran Biologi harus melalui penyelidikan (inkuri ilmiah), dan melalui penerapan konsep-konsep Biologidalam bentuk merancang dan membuat suatu karya atau produk. Dengan pembelajaran Biologi seperti ini siswa lebih dituntut siswa belajar lebih aktif pada pembelajaran Biologi.Belajar aktif merupakan salah satu hal penting untuk menunjang keberhasilan siswa dalam memperoleh hasil belajar yang optimal dan menggembirakan.

Oleh karena itu perlu pendekatan atau strategi pembelajaran untuk menyelesaikan permasalahan tersebut yaitu dengan menerapkan pendekatan saintifik (saintifik approach).Dimana merupakan suatu proses pembelajaran melalui pengamatan, bertanya, mencoba, kemudian menalar atau mengolah data informasi, menyajikan data atau informasi dilanjutkan dengan menganalisis, kemudian menyimpulkan.

\section{TINJAUAN PUSTAKA}

\section{A. Landasan dan Prinsip}

Pembelajaran dengan pendekatan saintifik adalah proses pembelajaran agar peserta didik secara aktif mengkonstruk konsep, hukum atau prinsip melalui tahapan-tahapan mengamati (mengidentifikasi atau menemukan masalah), merumuskan masalah, mengajukan atau merumuskan hipotesis, menumpulkan data dengan berbagai teknik, menganlisis data, menarik kesimpulan dan mengkomunikasikan konsep, hukum atau prinsip yang "ditemukan". Pendekatan saintifik dimaksudkan untuk memberikan pemahaman kepada peserta didik dalam mengenal, memahami berbagai materi menggunakan pendekatan ilmiah, bahwa informasi bisa berasal dari mana saja, kapan saja, tidak bergantung pada informasi searah dari guru.Oleh karena itu kondisi pembelajaran yang diharapkan tercipta untuk mendorong peserta didik dalam mencari tahu dari berbagai sumber melalui observasi dan bukan hanya diberi tahu (Kemdikbud, 2013).

Pembelajaran dengan pendekatan saintifik memiliki karakteristik sebagai berikut:

1. Berpusat pada peserta didik.

2. Melibatkan ketrampilan proses sains dalammengkonstruksi konsep, hukum atau prinsip.

3. Melibatkan proses-proses kognitif yang potensial dalam merangsang perkembangan intelek, khususnya keterampilan berpikir tingkat tinggi peserta didik.

4. Dapat mengembangkan karakter peserta didik.

Beberapa tujuan pembelajaran dengan pendekatan saintifik adalah:

1. Untuk meningkatkan kemampuan intelek, khususnya kemampuan berpikir tingkat tinggi siswa;

2. Untuk membentuk kemampuan siswa dalam menyelesaikan suatu masalah secara sistematik;

3. Terciptanya kondisi pembelajaran dimana siswa merasa bahwa belajar itu merupakan suatu kebutuhan;di perolehnya hasil belajar yang tinggi;

4. Untuk melatih siswa dalam mengomunikasikan ide-ide, khususnya dalam menulis artikel ilmiah;

5. Untuk mengembangkan karakter siswa;
Menurut
Sudarwan
(2013),

kurikulum 2013 menekankan pada dimensi pedagogik modern dalam pembelajaran, yaitu menggunakan pendekatan ilmiah. Pendekatan ilmiah (saintifik appoach) dalam pembelajaran sebagaimana dimaksud meliputi mengamati, menanya, menalar, mencoba, membentuk jejaring untuk semua mata pelajaran. Kurikulum 2013 menekankan penerapan pendekatan saintifik (meliputi: mengamati, menanya, mencoba, mengolah, menyajikan, menyimpulkan, dan mencipta untuk semua mata pelajaran).

Aspek-aspek pada pendekatan saintifik terintegrasi pada pendekatan keterampilan proses dan metode ilmiah Keterampilan proses sains merupakan seperangkat keterampilan yang digunakan para ilmuwan dalam melakukan penyelidikan ilmiah Keterampilan proses perlu dikembangkan melalui pengalaman- 
pengalaman langsung sebagai pengalaman pembelajaran (Rustaman, 2005).

\section{B. Pendekatan Pembelajaran}

Pembelajaran pada Kurikulum 2013 menggunakan pendekatan saintifik atau pendekatan berbasis proses keilmuan. Pendekatan saintifik dapat menggunakan beberapa strategi seperti pembelajaran kontekstual. Model pembelajaran merupakan suatu bentuk pembelajaran yang memiliki nama, ciri, sintak, pengaturan, dan budaya misalnya discovery learning, project-based learning, problembased learning, inquiry learning (Permendikbud, 2014).

Pendekatan saintifik dimaksudkan untuk memberi pemahaman kepada peserta didik untuk mengetahui, memahami, mempraktikkan apa yang sedang dipelajari secara ilmiah. Oleh karena itu, dalam proses pembelajaran diajarkan agar peserta didik pencari tahu dari berbagai sumber melalui mengamati, menanya, mencoba, mengolah, menyajikan, menyimpulkan, dan mencipta untuk semua mata pelajaran) (Sudarwan, 2013).

Komponen-komponen penting dalam mengajar menggunakan pendekatan saintifik:

a. Menyajikan pembelajaran yang dapat meningkatkan rasa keingintahuan (Foster a sense of wonder),

b. Meningkatkan keterampilan mengamati (Encourage observation),

c. Melakukan analisis (Push for analysis) dan

d. Berkomunikasi communication)

(Require

Dari keempat komponen tersebut dapat dijabarkan ke dalam lima praktek pembelajaran yaitu: mengamati, menanya, pengumpulan informasi, mengasosiasi, dan komunikasi.

Kelima langkah dalam pendekatan saintifik tersebut dapat dilakukan secara berurutan atau tidak berurutan, terutama pada langkah pertama dan kedua.Sedangkan pada langkah ketiga dan seterusnya sebaiknya dilakukan secara berurutan.Langkah ilmiah ini diterapkan untuk memberikan ruang lebih pada peserta didik dalam membangun kemandirian belajar serta mengoptimalkan potensi kecerdasan yang dimiliki. Peserta didik diminta untuk mengkonstruk sendiri pengetahuan, pemahaman, serta skill dari proses belajar yang dilakukan, sedangkan tenaga pendidik mengarahkan serta memberikan penguatan dan pengayaan tentang apa yang dipelajiri bersama peserta didik (Musfiqon, 2015).

\section{Penerapan Pendekatan Saintifik dalam Pembelajaran}

Kurikulum 2013 didasarkan pada prinsip-prinsip yang baru antara lain: (1) dari peserta didik diberi tahu menuju peserta didik mencari tahu, (2) dari guru sebagai satu-satunya sumber belajar menjadi belajar berbasis aneka sumber belajar, dan (3) dari pendekatan tekstual menuju proses sebagai penguatan penggunaan pendekatan ilmiah. Penerapan ketiga prinsip tersebut memerlukan kreativitas guru dalam mengarahkan, membimbing, dan memfasilitasi peserta didik.

Kompetensi dasar yang harus dicapai peserta didik adalah kompetensi, sikap, kompetensi pengetahuan, dan kompetensi keterampilan.Kompetensi sikap terkait dengan nilai-nilai yang bersifat umum, yaitu nilai spiritual (terkait dengan Kompetensi Inti ke-1) dan nilai-nilai sosial (terkait dengan Kompetensi Inti ke-2).Selain itu, pembelajaran sikap juga perlu dikaitkan dengan karakteristik mata pelajaran yang diajarkan.Sebagai contoh, sesuai dengan karakteristik dalam topik pencernaan makanan, kompetensi sikap yaitu disiplin, rasa percaya diri, berperilaku jujur, tangguh menghadapi masalah tanggungjawab, rasa ingin tahu, peduli lingkungan.

Pembelajaran biologi berdasarkan langkah-langkah pendekatan saintifik selanjutnya dijelaskan dalam uraian berikut. Mengamati

Mengamati merupakan landasan untuk melakukan kegiatan menanya atau mengajukan pertanyaan. Kegiatan ini dapat dilakukan dengan membaca sekilas bab yang terdapat di dalam buku siswa. Pada bagian awal bab bahkan terdapat peta konsep yang merupakan bagan susunan konsep-konsep pokok materi yang dipelajari. Selain itu, guru dapat memberikan sumber belajar lainnya (misalnya berupa tayangan video) sebagai objek pengamatan. 
Menanya

Dengan membaca sekilas uraian materi dan melakukan pengamatan berdasarkan sumber belajar lainnya, peserta didik selanjutnya dapat mengembangkan sejumlah pertanyaan sebagai langkah awal bagian inti pembelajaran.Selanjutnya guru bersamasama dengan seluruh peserta didik menyimpulkan pertanyaan-pertanyaan yang relevan dengan tujuan pembelajaran.

Mengumpulkan Informasi

Hasil kegiatan menanya merupakan landasan untuk melakukan kegiatan pengumpulan data atau informasi.Untuk melakukan kegiatan ini, guru perlu memberikan acuan kepada peserta didik pengetahuan tentang metode pengumpulan data seperti observasi, wawancara, dan dokumentasi.Dalam hal ini peserta didik dapat berbagi tugas untuk menemukan data atau informasi untuk menjawab pertanyaan yang telah dirumuskan.

Menalar

Menganalisis data untuk menindaklanjuti data yang diperoleh dengan cara memilah-milah dan mengkategorikannya sesuai dengan aspekaspek yang tercakup dalam pertanyaanpertanyaan yang diajukan. Menganalisis data juga dapat diartikan memadukan seluruh data yang diperoleh dari berbagai sumber belajar secara sistematis dan bermakna.

Mengkomunikasikan

Dalam langkah ini peserta didik secara kelompok mempresentasikan hasil diskusinya di depan kelas dan ditanggapi oleh kelompok yang lain. (Musfiqon, 2015).

\section{Model Pembelajaran Saintifik}

Model pembelajarandapat diartikan rencana konseptual yang berisi strategi, pendekatan,metode, teknik serta taktik pembelajaran yang telah disusun olehtenaga pendidik. Model pembelajaran merupakan akumulasi prosespembelajaran yang diterapkan dalam pembelajaran di kelas.

Dalam pendekatan saintifik ada tiga model pembelajaranyang dapat diterapkan, yaitu: (1) model pembelajaran berbasisproyek, (2) model pembelajaran berbasis masalah, dan (3) model pembelajaran berbasis inquiry. Untuk lebih jelasnya dipaparkansebagai berikut:
1. Pembelajaran berbasis proyek

Pembelajaran Berbasis Proyek

(Project Based Learning $=P j B L$ ) adalah model pembelajaran yang menggunakan proyek atau kegiatansebagai media pembelajaran. Peserta didik melakukan eksplorasi,penilaian, interpretasi, sintesis, dan mencari informasi untukmenghasilkan berbagai bentuk hasil belajar.

2. Pembelajaran berbasis masalah

Problem BasedLearning (PBL) dirancang dengan menghadirkan masalahmasalahyang kemudian peserta didik mendapat pengetahuan penting darimasalah yang dimunculkan. Lebih lanjut, peserta didik diharapkanmahir dalam memecahkan masalah dan memiliki model belajarsendiri serta memiliki kecakapan berpartisipasi dalam tim untukmenyelesaikan masalah secara kelompok. Proses pembelajarannyamenggunakan pendekatan yang sistemik untuk memecahkan masalahatau menghadapi tantangan yang relevan dalam kehidupan. Konsepini sesuai dengan definisi masalah yaitu sesuatu yang sulit dihadapi atau dimengerti.

3. Pembelajaran berbasis inkuiri

Pembelajaran inkuiri merupakan kegiatan pembelajaran yangmelibatkan secara maksimal seluruh kemampuan siswa untukmencari dan menyelidiki sesuatu (benda, manusia atau peristiwa)secara sistematis, kritis, logis, analitis sehingga mereka dapatmerumuskan sendiri penemuannya dengan penuh percaya diri.

\section{METODE PELAKSANAAN}

A. Lokasi dan Waktu Penelitian

Penelitian ini dilaksanakan di SMA Negeri Se-Kota Medan.Waktu penelitian direncanakan mulai dari Juli - September 2019.

\section{B. Metode Penelitian}

Metode penelitian yang digunakan adalah metode deskriptif untuk mengetahui bagaiamana penerapan langkah-langkah pendekatan saintifik di SMA Negeri Se-Kota Medan.

\section{Sumber Data}

Yang menjadi sumber data dalam penelitian ini adalah Guru Biologi dan siswa kelas XI di SMA Negeri 2 Medan, SMA Negeri 4 Medan, SMA Negeri 5 Medan, SMA Negeri 
8 Medan dan SMA Negeri 18 Medan. Teknik pengambilan sumber data dilakukan secara cluster random.

\section{Instrumen Penelitian}

Pada penelitian ini, instrumen yang digunakan adalah Observasi, Angket dan Wawancara.

\section{E. Metode Analisis Data}

1. Analisis Data Observasi

Data observasi digunakan untuk merefleksikan pembelajaran yang telah dilakukan dan diolah secara deskriptif. Data yang diobservasi adalah data observasi aktivitas guru, aktivitas siswa.

2. Analisis Data Penerapan Pendekatan Saintifik

Data penerapan pendekatan saintifik digunakan untuk mendeskripsikan penerapan pendekatan saintifikdi dalam proses pembelajaran Biologi yang telahdilaksanakan. Penerapan pendekatan saintifik di dalam pembelajaran dikatakan baik apabila sudah menerapkan tahap-tahap dari pendekatan saintifik, yaitu: tahap mengamati, tahap menanya, tahap mengumpulkan informasi, tahap menalar dan tahap mengkomunikasikan.

Penentuan nilai untuk tiap kriteria menggunakan persamaan yaitu rata-rata skor, skor tertinggi, skor terendah, selisih skor, dan kisaran nilai untuk tiap kriteria dengan rumus sebagai berikut:

a. Rata - rata skor $=\frac{\text { Jumlah Skor }}{\text { Jumlah Observer }}$

b. Skor Tertinggi $=$ aspek yang diamati $\mathrm{x}$ Skor Tertinggi Tiap Butir

c. Skor Terendah = aspek yang diamati $\mathrm{x}$ Skor Terendah Tiap Butir

d. Selisih Skor $=$ Skor Tertinggi - Skor Terendah

e. Kisaran nilai Untuk Tiap Kriteria = Selisih Skor

$\overline{\text { Jumlah Kriteria Penilaian }}$

(Sudjana, 2010)

a. Data Penilaian RPP Untuk Guru

Untuk menganalisis penilaian RPP dilakukan pada lembar penilaian RPP.Pada lembar penilaian terdapat 35 pertanyaan dan pengukuran skala penilaian yaitu antara 1 sampai 3 . Berdasarkan rumus yang telah ditentukan di atas, maka diperoleh data sebagai berikut:

\begin{tabular}{|c|c|}
\hline kor minimum & 35 \\
\hline Skor maksimum & 105 \\
\hline Maka kriteria: & \\
\hline Tidak Ada & $35-57$ \\
\hline Kurang Lengkap & $58-81$ \\
\hline Lengkap & $82-105$ \\
\hline
\end{tabular}

b. Data Penilaian Pembelajaran Untuk Guru

Untuk menganalisis penilaian pembelajaran dilakukan pada lembar penilaian guru.Pada lembar penilaian untuk guru terdapat 30 butir pertanyaan dan pengukuran skala penilaian guru untuk yaitu antara 1 sampai 5.Berdasarkan rumus yang telah dikemukakan di atas, maka diperoleh data sebagai berikut.

Skor minimum : 30

Skor maksimum : 150

Maka kriteria :

Baik Sekali (BS) : : $126-150$

Baik (B) : $101-125$

Kurang Baik (KB) : : $76-100$

Tidak Baik (TB) : $51-75$

Sangat Tidak Baik (STB) : $30-50$

c. Data Penilaian Pembelajaran Untuk Siswa

Untuk menganalisis penilaian pembelajaran dilakukan pada lembar penilaian pembelajaran untuk siswa.Pada lembar penilaian pembelajaran untuk siswa terdapat 20 butir pertanyaan dan pengukuran skala penilaian pembelajaran untuk siswa yaitu antara 1 sampai 5 . Berdasarkan rumus yang telah dikemukakan di atas, maka diperoleh data sebagai

berikut.

$\begin{array}{ll}\text { Skor minimum } & : 20 \\ \text { Skor maksimum } & : 100 \\ \text { Maka kriteria : } & \\ \text { Baik Sekali (BS) } & : 84-100 \\ \text { Baik (B) } & : 67-83 \\ \text { Kurang Baik (KB) } & : 50-66 \\ \text { Tidak Baik (TB) } & : 33-49 \\ \text { Sangat Tidak Baik (STB) } & : 20-32\end{array}$

d. Data Wawancara Untuk Guru

Untuk menganalisis wawancara untuk guru dilakukan pada lembar wawancara untuk guru.Pada lembar wawancara untuk guru terdapat 10 butir pertanyaan. Jawaban yang diberikan oleh guru, akan dianalisis dan dijabarkan dalam pembahasan.

e. Data Wawancara Untuk Siswa 
Untuk menganalisis wawancara untuk siswa dilakukan pada lembar wawancara untuk siswa.Pada lembar wawancara untuk siswa terdapat 10 butir pertanyaan. Jawaban yang diberikan oleh siswa, akan dianalisis dan dijabarkan dalam pembahasan.

\section{HASIL dan PEMBAHASAN}

\section{A. Hasil Penelitian}

1. Deskripsi Penelitian

Pelaksanaan penelitian ini dilakukan di SMA Negeri 2 Medan, SMA Negeri 4 Medan, SMA Negeri 5 Medan, SMA Negeri 8 Medan, dan SMA Negeri 18 Medan. Penelitian berlangsung dari 19 Agustus s/d 31 Agustus 2019. Namun sebelum penelitian dilaksanakan, peneliti telah melakukan observasi awal ke sekolah untuk melihat situasi dan kondisi sekolah yang akan menjadi lokasi penelitian. Yang menjadi sumber data dalam penelitian ini adalah Guru Biologi dan Siswa kelas XI. Metode penelitian yang dilakukan adalah deskriptif untuk mengetahui penerapan langkah-langkah pembelajaran dengan pendekatan saintifik dalam kurikulum 2013 di SMA Negeri Se-Kota Medan.

2. Observasi Guru dan Siswa

Observasi Guru dan Siswa dilaksanakan pada saat kegiatan pembelajaran berlangsung. Hal-hal yang diobservasi adalah langkah-langkah pendekatan saintifik yaitu mengamati, menanya, mengumpulkan informasi, menalar, mengkomunikasikan.

Berdasarkan hasil observasi guru dan siswa, diketahui bahwa guru dan siswa telah melaksanakan langkah-langkah pendekatan saintifik yaitu mengamati.
Berdasarkan hasil observasi guru dan siswa diketahui bahwa pada G.1 tahap mengamati, menanya, mengumpulkan informasi telah terlaksana dengan baik. Namun pada tahap menalar dan mengkomunikasikan tidak terlaksana karena guru masih terfokus pada materi dengan menggunakan power point materi sel dan belum dilaksanakan diskusi. Pada G.2 tahap mengamati, menanya, mengumpulkan informasi, menalar dan mengkomunikasikan sudah terlaksana dengan baik karena pada saat observasi. Pada G.3 tahap mengamati, menanya, mengumpulkan informasi telah terlaksana dengan baik, namun tahap menalar dan mengkomunikasikan belum terlaksana karena pada saat observasi metode pembelajaran yang terlaksana adalah ceramah dan tanya jawab. Pada G.4 telah terlaksana dengan baik kelima tahap mengamati, menanya, mengumpulkan informasi, menalar dan mengkomunikasikan. Pada G.5 tahap mengamati, menanya, mengumpulkan informasi telah terlaksana dengan baik. Tahap menalar dan mengkomunikasikan belum terlaksana karena guru masih terfokus pada materi dengan menggunakan metode ceramah dan tanya jawab.

3. Angket Penilaian RPP

Angket Penilaian RPP bertujuan untuk mengetahui apakah komponen RPP telah sesuai dengan pendekatan saintifik. Angket terdiri dari 35 pertanyaan yang terangkum dalam 10 komponen RPP. Skor setiap pertanyaan adalah 1,2 , dan 3 . Hasil angket penilaian RPP berdasarkan komponen RPP disajikan dalam tabel berikut ini:

\begin{tabular}{|c|c|c|c|c|c|c|}
\hline \multirow[b]{2}{*}{ No } & \multirow[b]{2}{*}{ Komponen RPP } & \multicolumn{5}{|c|}{ Skor } \\
\hline & & G.1 & G.2 & G.3 & G.4 & G.5 \\
\hline 1. & Identitas Mata Pelajaran & 3 & 3 & 3 & 3 & 3 \\
\hline 2. & Kompetensi Inti dan Kompetensi Dasar & 6 & 6 & 6 & 6 & 6 \\
\hline 3. & Indikator Pencapaian Kompetensi & 9 & 9 & 9 & 9 & 7 \\
\hline 4. & Tujuan Pembelajaran & 8 & 8 & 8 & 8 & 8 \\
\hline 5. & Materi Pembelajaran & 11 & 12 & 12 & 12 & 12 \\
\hline 6. & Metode Pembelajaran & 8 & 8 & 8 & 8 & 8 \\
\hline 7. & Media Pembelajaran & 8 & 8 & 8 & 8 & 8 \\
\hline 8. & Sumber Pembelajaran & 8 & 8 & 8 & 8 & 8 \\
\hline 9. & Langkah-Langkah Pembelajaran & 27 & 26 & 24 & 25 & 24 \\
\hline 10. & Penilaian Proses dan Hasil Belajar & 12 & 12 & 12 & 12 & 12 \\
\hline & umlah skor & 100 & 100 & 97 & 99 & 96 \\
\hline
\end{tabular}


Berdasarkan data hasil penelitian diperoleh infomasi bahwa semua guru telah merencanakan pembelajaran yaitu merancang RPP dengan lengkap. Sepuluh komponen RPP yang diamati yaitu identitas mata pelajaran, kompetensi inti dan kompetensi dasar, indikator pencapaian kompetensi, tujuan pembelajaran, materi pembelajaran, metode pembelajaran, media pembelajaran, sumber pembelajaran, langkah-langkah pembelajaran, serta penilaian proses dan hasil belajar telah terangkum dengan lengkap dalam RPP. Hal ini menunjukkan bahwa guru tidak mengalami kesulitan dalam merencanakan pembelajaran yaitu RPP.

4. Angket Penilaian Pembelajaran Untuk Guru

Angket penilaian pembelajaran untuk guru bertujuan agar mengetahui apakah kegiatan pembelajaran telah sesuai dengan RPP dan telah menerapkan langakah-langkah pendekatan saintifik yaitu 5 M (mengamati, menanya, mengumpulkan informasi, menalar, mengkomunikasikan). Angket terdiri dari 30 pertanyaan yang terangkum dalam 3 aspek yang diamati antara lain kegiatan pendahuluan (3 pertanyaan), kegiatan inti (25 pertanyaan) dan penutup (2 pertanyaan). Skor angket setiap pertanyaan yaitu 1 = Sangat tidak baik, 2 = Tidak baik, $3=$ Cukup baik, $4=$ Baik, 5 = Sangat baik .

Hasil angket penilaian pembelajaran untuk guru yang lebih mendetail dapat dilihat di lampiran. Hasil angket penilaian pembelajaran dirangkum dalam tabel berikut ini:

\begin{tabular}{|c|l|c|c|c|c|c|}
\hline \multirow{2}{*}{ No } & \multicolumn{5}{|c|}{ Aspek Yang Diamati } & \multicolumn{4}{c|}{} \\
\cline { 3 - 7 } & & G.1 & G.2 & G.3 & G.4 & G.5 \\
\hline 1. & Kegiatan Pendahuluan & 14 & 13 & 15 & 15 & 14 \\
\hline 2. & Kegiatan Inti & & & & & \\
\hline & a. Langkah-langkah Pembelajaran & 20 & 18 & 17 & 20 & 18 \\
\hline & b. Pendekatan Pembelajaran & 51 & 45 & 48 & 47 & 46 \\
\hline & c. Pemanfaatan Media dan Sumber Pembelajaaran & 15 & 14 & 12 & 15 & 14 \\
\hline & d. Ketertlibatan Siswa dalam Pembelajaran & 13 & 13 & 13 & 13 & 13 \\
\hline & e. Penilaian Proses dan Hasil Belajar & 9 & 9 & 9 & 10 & 9 \\
\hline & f. Penggunaan Bahasa & 10 & 10 & 10 & 10 & 10 \\
\hline 3. & Penutup & 10 & 10 & 8 & 8 & 10 \\
\hline & Jumlah Skor & $\mathbf{1 4 2}$ & $\mathbf{1 3 2}$ & $\mathbf{1 3 2}$ & $\mathbf{1 3 8}$ & $\mathbf{1 3 4}$ \\
\hline & Kategori & BS & BS & BS & BS & BS \\
\hline
\end{tabular}

Berdasarkan data hasil angket penilaian pembelajaran untuk semua guru, diperoleh informasi bahwa guru telah melaksanakan kegiatan pendahuluan dengan sangat baik.Pada kegiatan inti pelaksanaan masing-masing aspek yang dinilai yaitu langkah-langkah pembelajaran (sangat baik), pendekatan pembelajaran (baik), pemanfaatan media dan sumber pembelajaran (sangat baik), keterlibatan siswa dalam pembelajaran (baik), penilaian proses dan hasil belajar (sangat baik), penggunaan bahasa (sangat baik).Pada kegiatan penutup terlaksana dengan sangat baik.
5. Angket Penilaian Pembelajaran Untuk Siswa

Angket penilaian pembelajaran untuk siswa bertujuan untuk mengetahui penerapan langkah-langkah pendekatan saintifik oleh guru dalam proses belajar mengajar di kelas. Angket terdiri dari 20 pertanyaan yang dibagi menjadi 10 indikator yaitu:

1. Keterampilan membuka pelajaran,

2. Keterampilan menjelaskan,

3. Keterampilan menggunakan media pembelajaran,

4. Keterampilan menerapkan metode,

5. Keterampilan melakukan penilaian,

6. Keterampilan menutup pembelajaran, 
7. Memanfaatkan Teknologi Infomasi,

8. Sikap Guru,

9. Memfasilitasi Pengembangan Potensi Peserta Didik,

10.Mengembangkan materi secara kreatif,

Dari hasil angket diperoleh skor yaitu (1) = sangat tidak baik, (2) = tidak baik, (3) = kurang baik, (4) = baik dan (5) = baik sekali. Total responden sebanyak 171 orang. Untuk G.1 responden berjumlah 36 orang, G.2 berjumlah 35 orang, G.3 berjumlah 36 orang, G.4 berjumlah 36 orang dan G.5 berjumlah 28. Hasil angket penilaian pembelajaran untuk siswa pada masing-masing sekolah dirangkum dalam tabel berikut:

\begin{tabular}{|c|l|c|c|c|c|c|}
\hline \multirow{2}{*}{ No } & \multicolumn{1}{|c|}{ Indikator } & \multicolumn{3}{c|}{ Skor } \\
\cline { 3 - 7 } & & G.1 & G.2 & G.3 & G.4 & G.5 \\
\hline 1. & Keterampilan membuka pelajaran & 277 & 315 & 231 & 341 & 204 \\
\hline 2. & Keterampilan menjelaskan & 690 & 779 & 723 & 821 & 582 \\
\hline 3. & Keterampilan menggunakan media & 339 & 393 & 344 & 436 & 313 \\
\hline 4. & Keterampilan menerapkan metode & 246 & 294 & 241 & 322 & 181 \\
\hline 5. & Keterampilan melakukan penilaian & 166 & 170 & 163 & 166 & 127 \\
\hline 6. & Keterampilan menutup pembelajaran & 411 & 467 & 378 & 449 & 266 \\
\hline 7. & Memanfaatkan teknologi infomasi & 109 & 120 & 96 & 112 & 108 \\
\hline 8. & Sikap guru & 119 & 171 & 157 & 146 & 110 \\
\hline 9. & $\begin{array}{l}\text { Memfasilitasi pengembangan } \\
\text { potensi peserta didik }\end{array}$ & 98 & 133 & 110 & 142 & 103 \\
\hline 10. & Mengembangkan materi secara kreatif & 154 & 149 & 119 & 147 & 70 \\
\hline & Rata-rata (skor/jlh.responden) & 72,47 & 85,46 & 71,17 & 85,61 & 73,71 \\
\hline & Kategori & B & BS & B & BS & B \\
\hline
\end{tabular}

Untuk keseluruhan hasil angket guru, maka di peroleh rata-rata skor kelima guru yaitu 77,68 dengan kategori Baik. Dapat disimpulkan bahwa semua guru telah melaksanakan pembelajaran dengan baik.

Pada penilaian untuk tiap-tiap indikator, maka diperoleh nilai yang lebih mendetail.Pada keterampilan melakukan penilaian, siswa berpendapat bahwa guru telah melaksanakannya dengan kategori sangat baik.

Pada keterampilan membuka pelajaran, keterampilan menjelaskan, keterampilan menggunakan media pembelajaran, keterampilan menutup pembelajaran, sikap guru dan mengembangkan materi secara kreatif sudah terlaksana dengan kategori baik.

Namun pada indikator menerapkan metode dan memfasilitasi pengembangan potensi peserta didik, para siswa menilai bahwa guru kurang baik melaksanakannya. Menurut peneliti, hal ini dapat terjadi karena siswa belum mengetahui apa saja metode pembelajaran yang diterapkan oleh guru. Dalam prakteknya mungkin guru telah melaksanakan namun karena siswa tidak tahu tentang metode tersebut maka siswa menganggap bahwa metode guru hanya ituitu saja.Dalam hal pengembangan potensi peserta didik, peneliti berpendapat kemungkinan bahwa guru lebih berfokus pada penyelesaian materi sehingga pengembangan potensi peserta didik menjadi kurang terlaksana dengan baik.

\section{Wawancara}

Berdasarkna hasil wawancara Guru diperoleh informasi bahwa guru setuju dengan pendekatan saintifik melalui tahapan 5M, dan telah menerapkan pembelajaran biologi menggunakan pendekatan saintifik, namun masih mengalami kendala dalam merencanakan yaitu pembuatan RPP. Dalam penerapan, siswa sangat senang dan tertarik dengan pendekatan saintifik sehingga penyampaian materi berjalan dengan lancar. Untuk menstimulus siswa, guru menyajikan informasi faktual, memberi pertanyaan untuk memancing keingintahuan, dan melalui gambar. 
Untuk wawancara siswa, dipilih sebanyak 5 orang pada setiap sekolah, jadi total responden adalah 25 orang.Berdasarkan hasil wawancara siswa diperoleh data sebagai berikut: Sebagian besar responden (92\%) mengetahui tentang kurikulum 2013 dan 8\% tidak mengetahuinya. Menurut 68\% responden guru selalu menjelaskan model pembelajaran yang dipakai, sementara $28 \%$ kadang-kadang dan $1 \%$ responden menyatakan guru tidak pernah menjelaskannya. $\quad 80 \% \quad$ responden mengetahui pendekatan saintifik dalam pembelajaran biologi, dan 20\% tidak mengetahui. Menurut $84 \%$ responden, guru biologi menggunakan pendekatan saintifik, sementara $12 \%$ menyatakan kadang-kadang dan 4\% tidak menggunakan. Namun 92\% reponden mengalami kendala ketika menerima pembelajaran biologi dengan pendekatan saintifik, sementara 8\% tidak mengalami kendala. Cara mengatasi kendala tersebut responden membaca/ belajar, menggunakan internet, bertanya kepada guru dan teman. Semua responden $(100 \%)$ menyatakan pembelajaran biologi di kelas pernah memakai sumber dari internet. Sebanyak $76 \%$ responden menyatakan sering bertanya kepada guru, 16\% jarang, $8 \%$ tidak pernah. Sebagian besar responden (92\%) memyatakan pernah membuat diskusi kelompok ketika belajar biologi, sedangkan $8 \%$ menyatakan tidak pernah. Sebanyak 84\% responden memaparkan hasil diskusi di depan kelas, sementara 16\% tidak memaparkan.

\section{B. Pembahasan}

Berdasarkan data yang diperoleh, maka peneliti akan membahas secara rinci tentang penerapan langkah-langkah pendekatan saintifik melalui dua bagian yaitu perencanaan pembelajaran dan pelaksanaan pembelajaran.

1. Perencanaan Pembelajaran

Komponen RPP yang dinilai antara lainIdentitas Mata Pelajaran, Kompetensi Inti dan Kompetensi Dasar, Indikator Pencapaian Kompetensi, Tujuan Pembelajaran, Materi Pembelajaran, Metode Pembelajaran, Media Pembelajaran, Sumber Pembelajaran, Langkah-langkah Pembelajaran, Penilaian Proses dan Hasil
Belajar.Berdasarkan hasil data yang diperoleh, semua guru memiliki RPP yang lengkap.Hal ini mengindikasikan bahwa guru tidak mengalami kesulitan dalam merancang RPP dengan pendekatan saintifik.

2. Pelaksanaan Pembelajaran

$$
\text { Penilaian pelaksanaan }
$$

pembelajaran berupa penerapan pendekatan saintifik oleh guru biologi dalam proses pembelajaran dikelas yang terbagi dalam tiga kegiatan yaitu:

a. Kegiatan pendahuluan

Berdasarkan hasil penelitian, guru telah melaksanakan kegiatan pendahuluan tetapi masih ada beberapa hal yang kurang merata saat disampaikan seperti memberikan motivasi dan Menjelaskan kompetensi dan indikator pembelajaran yang akan dicapai, cakupan materi dan teknik penilaian yang akan dilakukan. Dapat disimpulkan bahwa guru sudah melaksanakan kegiatan pendahuluan dengan sangat baik.

b. Kegiatan Inti

Berdasarkan hasil penelitian, kegiatan inti dilaksanakan dengan pendekatan saintifik yang terbagi dengan langkah 5M, yaitu:

1) Mengamati

Berdasarkan hasil penelitian, diketahui bahwa guru telah memfasilitasi siswa untuk melakukan proses mengamati, menggunakan media saat mengajar dan menstimulus siswa untuk melakukan suatu pengamatan. Metode mengamati memiliki keunggulan tertentu, seperti menyajikan media obyek secara nyata sehingga peserta didik senang, tertantang dan mudah pelaksanaanya.Dapat disimpulkan bahwa guru telah menerapkan Mengamati dengan baik begitu pula dengan siswa yang antusias.

2) Menanya

Pada kegiatan menanya, guru telah memfasilitasi siswa untuk melakukan proses menanya, merangsang siswa sehingga memiliki rasa ingin tahu, memberikan pertanyaan kepada siswa, dan mengaitkan materi pembelajaran dengan pengetahuan lain yang relevan. Sesuai hasil penelitian dimana siswa dipancing rasa ingin tahunya untuk bertanya, sehingga prinsip 5M dapat terlaksana dengan baik 
dan menghasilkan pembelajaran yang lebih baik. Kompetensi yang diharapkan dalam kegiatan menanya ini adalah mengembangkan kreativitas, rasa ingin tahu, kemampuan merumuskan pertanyaan untuk membentuk pikiran kritis yang perlu untuk hidup cerdas dan belajar sepanjang hayat.

3) Mengumpulkan Informasi

Berdasarkan hasil penelitian diketahui bahwa guru telah memfasilitas siswa untuk berdiskusi, mengumpulkan informasi tentang sel dan guru telah menstimulus siswa untuk mengumpulkan informasi sehingga siswa mampu memcahkan sebuah masalah yang berkaitan dengan sel.

Kompetensi yang diharapkan dalam kegiatan mengumpulkan informasi ini adalah mengembangkan sikap teliti, jujur, sopan, menghargai pendapat orang lain, mampu berkomunikasi, menerapkan kemampuan mengumpulkan informasi melalui berbagai cara yang dipelajari, mengembangkan kebiasaan belajar dan belajar sepanjang hayat.

4) Menalar

Dalam kegiatan menalar diharapkan guru dapat memfasilitasi siswa untuk melakukan proses menalar, memunculkan masalah pada siswa sehingga siswa mampu menalar setiap masalah dengan baik, guru mengutamakan keterlibatan siswa dalam pemanfaatan media pembelajaran dan memantau kemajuan belajar siswa saat melakukan diskusi kelompok.

Berdasarkan hasil penelitian diketahui bahwa kegiatan menalar belum terlaksana dengan baik.Hal ini terjadi karena pemanfaatan media yang kurang optimal sehingga siswa belum mampu menalar setiap masalah dengan baik. Kompetensi yang dikembangkan dalam proses menalar adalah mengembangkan sikap jujur, teliti, disiplin, taat aturan, kerja keras, mampu menerapkan prosedur dan mampu berfikir induktif secara deduktif dalam menyimpulkan.

5) Mengkomunikasikan Dalam

kegiatan mengkomunikasikan, guru diharapkan mampu memberikan kesempatan kepada siswa agar mengkomunikasikan sebuah masalah tentang sel yang sedang didiskusikan di depan kelas, dan mampu menyusun rangkuman pembelajaran dengan melibatkan siswa.

Berdasarkan hasil penelitian diketahui bahwa guru telah melaksanakan kegiatan mengkomunikasikan dengan baik.Kompetensi yang diharapkan dalam kegiatan ini adalah mengembangkan sikap jujur, teliti, toleransi, kemampuan berpikir sistematis, mengungkapkan pendapat dengan singkat dan jelas, dan mengembangkan kemampuan berbahasa yang baik dan benar. Kegiatan mengkomunikasikan akan berdampak terhadap siswa dan pembelajaran yang terlihat bahwa guru masih menjadi tuntunan atau yang berperan aktif didalamnya.

c. Kegiatan Penutup

Berdasarkan hasil penelitian, kegiatan penutup telah dilaksanakan dengan baik., guru memberikan evaluasi atau menyampaikan materi pada pertemuan berikutnya.

\section{SIMPULAN}

Kesimpulan dan Saran yang diperoleh dari penelitian ini adalah sebagai berikut:

Yang menjadi kesimpulan adalah:

1. Penerapan pendekatan saintifik dalam Kurikulum 2013 di SMA Negeri Se-Kota Medan telah terlaksana dengan baik.

2. Kendala yang dihadapi guru Biologi dalam penerapan pendekatan saintifik dalam Kurikulum 2013 di SMA Negeri Se-Kota Medan antara lain adalah kurangnya keterampilan menerapkan metode, kurang memanfaatkan teknologi infomasi dan kurang memfasilitasi pengembangan potensi peserta didik.

3. Sarana dan prasarana sekolah yang mendukung penerapan pendekatan saintifik dalam Kurikulum 2013 adalah media pembelajaran yang tepat dan internet. 


\section{DAFTAR PUSTAKA}

Anam, Khoerul. 2017. Analisis Implementasi Pendekatan Saintifik Terhadap Pembelajaran Penjasorkes Kelas X SMA Negeri 1 Minggir. Yogyakarta: Fakultas Ilmu Keolahragaan Universitas Negeri Yogyakarta.

Askar, Ika Sartika. 2016. Penerapan Pendekatan Scientific Dalam Meningkatkan Hasil Belajar Biologi Konsep Sistem Ekskresi Manusia Siswa Kelas VIII A SMP Negeri 2 Sibulue Kabupaten Bone.Jurnal Perspektif, Nomor 2 Desember 2016.

Kementerian Pendidikan dan Kebudayaan RI. 2013. Salinan Lampiran Peraturan Menteri Pendidian dan Kebudayaan Republik Indonesia No. 65 tentang Standar Proses Pendidikan Dasar dan Menengah.

Mulyaningsih. 2015. Implementasi Pendekatan Saintifik Pada Mata Pelajaran Agama Islam dan Budi Pekerti Kelas VII SMP IT Abu Bakar Yogyakarta TP. 2014/2015

Musfiqon. 2015. Pendekatan pembelajaran Saintifik. Nizlamia Learning Center.Sidoarjo.

Permendikbud No. 103 Tahun 2014 Tentang Pembelajaran Pada Pendidikan Dasar dan Pendidikan Menengah.

Prihadi, Bambang. 2014. Penerapan Langkah-Langkah Pembelajaran Dengan Pendekatan Saintifik Dalam Kurikulum 2013.Disampaikan dalam In House Traning Implementasi Kurikulum 2013 di SMPN 8 Kota Pekalongan tangal 23-24 Mei 2014.
Rahmatika, Ummu dan Amrizal.2018. Pemetaan Pembelajaran Biologi Berbasis Scientific Approach Di SMA Negeri 1 Binjai.Jurnal Pelita Pendidikan Vol. 6 No. 01.

Rakhmawati.2015. Penerapan Pendekatan Saintifik Pada Mata Pelajaran Biologi di Kelas XI IIS 3 SMAN Jayaloka Tahun Pelajaran 2014/2015.

Rasyid, Nur Alfiah. 2018. Pengaruh Penerapan Pendekatan Saintifik Terhadap Peningkatan Minat Belajar Peserta Didik Pada Pembelajaran Akidah Akhlak Di MA Manongkoki Kab.Takalar.Skripsi.UIN Alauddin.Makasar.

Rustaman, N. Y. 2005. Strategi Belajar Mengajar Biologi. Malang: UM Press.

Sani, A. R..2014. Pembelajaran Saintifik untuk Implementasi 2013.PT Bumi Aksara. Jakarta

Saubas, Udin. 2015. Implementasi Kurikulum 2013 Melalui Penerapan Pendekatan Saintifik Dalam Pembelajaran Bahasa Indonesia Berbasis Teks Di Sekolah Menengah Pertama (SMP). Jurnal Pendidikan Edukasi. Volume 13 No. 1 Januari 2015

Sudarwan. 2013. Pendekatan-Pendekatan Ilmiah Pada Pembelajaran. Pusbangprodik.

Sudjana, Metode Statistika, Bandung: Penerbit Tarsito, 2010.

Susilo, Muhammad Joko. 2016. Pembelajaran IPA Biologi Berbasis Scientific Approach di SMP Muhammadiyah 2 Depok Sleman. Proceeding Biology Education Conference. Vol 13 (1) 